\title{
BLENDING THE SECULAR AND SACRED: INSTRUMENTAL TEXTURES IN SEVENTEENTH-CENTURY WORSHIP
}

In the seventeenth century composers orchestrated liturgical settings with ensembles of string and brass instruments integrating elements of the Latin sacred concerto and the oratorio into music for the Mass and daily Offices. Furthermore, the incorporation of the traditionally secular genre of the sonata into these liturgical genres demonstrates the permeable boundary between the sacred and secular realms of the period. In this paper, I will examine how Salzburg composer Andreas Hofer uses instrumental textures to enhance expressive meaning and foster drama in the inherently un-dramatic genre of Offertory in his printed collection, Ver Sacrum seu Flores, published in 1677.

The use of instruments in sacred contexts hearkens back to Venice in the late sixteenth century and has been discussed by scholars such as Stephen Bonta and Eleanor Selfridge-Field, both of whom have written about instrumental ensembles used in Venetian sacred music ca. 1600. ${ }^{1}$ Moreover, Massimo Troiano provides direct testimony for the integration of instruments in liturgical music at the Munich court in a colla parte construction as early as $1568 .{ }^{2}$ In his article on the uses of the Sonata da chiesa, Bonta stresses the functionality of musical style in sacred contexts and describes how sixteenth-century instrumental ensembles held roughly the same liturgical function as the organ - to complement and augment the vocal ensemble when need be and to accompany liturgical actions such as the Elevation of the Eucharist or the collection of the Offertory. ${ }^{3}$

The seventeenth century was a transitional period for instrumental music in sacred performance contexts. In his dissertation, Instruments in sacred vocal music

1 SELFRIDGE-FIELD, Eleanor. Venetian Instrumental Music from Gabrieli to Vivaldi. New York and Washington: Praeger Publishers, 1974, and BONTA, Stephen. The Uses of the Sonata da chiesa. Journal of the American Musicological Society, 1969, vol. 22, pp. 54-84. Massimo Troiano (Venice, 2/1569). Originally cited in C. van Borren, Orlande de Lassus et la musique instrumentale Le revue musicale May 1922, p. 116. 
at Braunschweig-Wolfenbüttel, James Leonard Brauer described the transition of instrumental music from colla parte practice to the eventual incorporation of idiomatic instrumental textures into sacred music. ${ }^{4}$ This integration would have created expressive complications, since upon hearing instrumental sounds, contemporary listeners' minds would most likely have been drawn to secular activities, as these ensembles usually accompanied royal processions, weddings, and public festivals or were heard during concerts at city hall. ${ }^{5}$ However, the ability of instrumental music to express extramusical meaning through signs and allegory was simultaneously developing, allowing instrumental textures to communicate sacred or secular ideas. ${ }^{6}$ In The Order of Things, Michel Foucault described the destabilization of the relationship between sign and signifier in the late sixteenth and early seventeenth centuries. ${ }^{7}$ According to Foucault, while a sixteenth-century sign was an integral part of that which it signifies, a seventeenth-century sign functioned more as a mode of representation. ${ }^{8}$ Writing about instrumental passages in the music of Claudio Monteverdi, Gary Tomlinson and Jeffrey Kurtzman imply that this severing of the close link between sign and signifier allowed pure music to assert itself as a communicative device independent of words. ${ }^{9}$ According to Kurtzman, once a musical symbol expressing an idea or emotion "was established as convention, it was capable of conveying its significance in the absence of words." 10 Therefore, the necessity of actual words, or signifiers, to communicate meaning in music diminished and wordless instrumental accompaniment could become an important tool for the expression of ideas, both sacred and secular.

Instrumental music was in high demand at the Salzburg court during the employ of Andreas Hofer from 1665 until his death in 1684. During this prosperous

4 BRAUER, James Leonard. Instruments in sacred vocal music at Braunschweig-Wolfenbüttel: a study of changing tastes in the seventeenth century. Ph.D. Dissertation, City University of New York, 1983, p. 286.

5 KORRICK, Leslie. Instrumental Music in the Early $16^{\text {th }}$-Century Mass: New Evidence. Early Music, 1990, vol. 18, p. 360.

6 OTTO, Craig Allen. Symbol structures in Central European church music: aspects of the word-tone relationship in the mid- to late seventeenth century. Ph.D. Dissertation, Syracuse University, 1978, pp. 209-210. Otto gives the example of Schmelzer's Missa nuptialis where a chorus syllabically declaims the text while the obbligato violin parts achieve the concept allegory of resurrection with ascending melodic figures.

7 FOUCAULT, Michael. The Order of Things, An Archaeology of the Human Sciences. New York: Vintage Books, 1994. Originally published as Les Mots et les choses: Une archéologie des sciences humaines by Editions Gallimard in 1966.

8 Ibid., p. 129.

9 TOMLINSON, Gary. Monteverdi and the End of the Renaissance. Oxford: Clarendon Press, 1987, and KURTZMAN, Jeffrey. Monteverdi's changing aesthetics: A Semiotic Perspective. In Festa musicological: Essays in honor of George J. Buelow. Edited by Thomas Mathiesen and Benito Rivera. Stuyvesant, NY: Pendragon Press, 1995, pp. 233-255.

10 KURTZMAN, Jeffrey. Monteverdi and Early Baroque Aesthetics: the View from Foucault. In Il Madrigale oltre il madrigal: Dal Barocco Al Novecentodestino di una Forma e Problemi di Analisi. Edited by Alberto Colzani. Como: Antiquae Musicae Italicae Studiosi, 1994, p. 115. 
time, Salzburg was ruled by Prince Archbishop Maximilian Gandolph, who held the musical arts, especially instrumental music, in very high esteem and therefore designated considerable financial resources to improve the quality and to substantially grow the breadth of the performance forces of the court. Violin virtuoso Heinrich Biber deserted his position at the neighboring court of Kroměřžz around 1670 to serve Maximilian Gandolph in Salzburg, and Maximilian also hired instrumental composer Georg Muffat in the late 1670s. ${ }^{11}$ It was in this atmosphere that Hofer cultivated a rich repertoire of liturgical music for voices accompanied by orchestrations of violins, violas, flutes, cornettos, and trombones, an oeuvre containing settings of Offertories, Masses, Requiems, Psalms, Magnificats, Litanies, and the Te Deum.

Andreas Hofer's collection of Offertories for five voices and five instruments, Ver sacrum seu flores, was printed in 1677 by Salzburg printer Johann Baptist Mayr and was dedicated to Maximilian Gandolph. While the majority of the part books of the collection are extant in the Salzburg Cathedral Archive, the partbooks for the bass voice, first violin, and a fifth instrumental part can be found today only in the archive of the Benedictine Abbey in Ottobeuren, Bavaria. The collection opens with an Offertory for the feast of the Nativity and concludes with a piece for the Common of Virgins and Martyrs. See Table 1.

\begin{tabular}{|r|l|l|l|l|}
\hline & Title & Feast & $\begin{array}{l}\text { Secondary } \\
\text { Instruments }\end{array}$ & $\begin{array}{l}\text { 5th Instrumental } \\
\text { Part }\end{array}$ \\
\hline 1 & Dum medium silentium & Nativitas domini & trombones & Trombone III \\
\hline 2 & Adeste fideles & Stephani & violas & Fagotto \\
\hline 3 & Gaudent Caeli & Joannis Apost. Evang. & trombones & Trombone III \\
\hline 4 & Vox in Rama & Innocentium & violas & Bassus Viola \\
\hline 5 & Ad cunas Jesuli & Circumcisio Domini & violas & Fagotto \\
\hline 6 & Consurgites fortes & Purification of the BVM & trombones & Trombone III \\
\hline 7 & Resurgenti Deo & Resurrectio Domini & trombones & Trombone III \\
\hline 8 & Vidis con junctos viros & Philippi et Jacobi Apostolorum & violas & Fagotto \\
\hline 9 & Ecce Cruce Domini & Crux Inventio & trombones & Trombone III \\
\hline 10 & Caeli cives Jubilate & Ascensio Domini & violas & Fagotto \\
\hline 11 & O suavis aura Caeli & Pentecost & trombones & Trombon III \\
\hline 12 & Panis candidissime & De Venerabile Sacramento & violas & Bassus Viola \\
\hline 13 & Audite insulae & Joannis Baptistae & trombones & Trombon III \\
\hline 14 & Egredimini filiae Sion & BMV & violas & Fagotto \\
\hline 15 & Estote fortes in bello & De Apostolis & trombones & Trombone III \\
\hline 16 & Quam splendita & De uno Martyre & violas & Fagotto \\
\hline 17 & Ad cereni caeli & De Confessore & violas & Fagotto \\
\hline 18 & Ad festum virginis & & Tenor II & Bassus II \\
\hline
\end{tabular}

Table 1. Contents of Hofer's Ver sacrum seu flores (Salzburg, 1677)

11 CHAFE, Eric. The Church Music of Heinrich Biber. Ann Arbor, Michigan: UMI Research Press, 1987, p. 1. 
On the title page, Hofer indicates that the contents are suitable for "holidays that occur throughout the year, together with certain ones from the ordinary [time]". ${ }^{12}$ Hofer includes seven Offertories for the "ordinary time" of the church year between the feast of the Ascension and the beginning of Advent including settings for the Feasts of Corpus Christi, John the Baptist, and for the Commons of the Blessed Virgin, the apostles, the martyr, the confessors, and virgins and martyrs. However, the majority of the 18 offertories included are for feasts of the Temporale, the movable feasts throughout the church year, such as the Nativity, Easter, Ascension and Pentecost among others.

In a special note to the performers, Hofer acknowledges the high demand for music for the Offertory expressing his great hope that "the Offertory should flourish in many places on account of public demand." ${ }^{13}$ Despite the high demand, Hofer alludes to the flexible nature of the contents of the collection. On the title page Hofer indicates that these works are to be used "chiefly for Offertories", ${ }^{14}$ which alludes to the fact that while the works were designed for performance during the offertory, they also have the flexibility for performance in other contexts - liturgical or possibly devotional. Likewise, in his note to the "dear reader", Hofer indicates that he conceived of the collection as a cursory, pragmatic group of pieces that he had not, "embellished them for magnificence, but [rather composed them] as exceptional craftsmanship, so that they may be of service to many". ${ }^{15}$ Furthermore, Hofer strays far from the liturgically prescribed texts for the Proper of the Mass, setting a wide variety of centonized texts from multiple sources. Therefore, the texts of the collection do not inextricably link these pieces to performance for the Offertory. In the piece for the Feast of the Innocents, Vox in Rama, for example, Hofer opens with a quote from the prophet Jeremiah in Matthew 2:18 and continues setting the text of a Latin hymn for the Feast of the Innocents, Agni balant.

Each piece in the collection is accompanied by two violins, a standard instrumentation in sacred concertos of the early seventeenth century. These violins serve various musical roles providing harmonic accompaniment, engaging in dramatic melodic flourishes, and contributing to imitative textures. Hofer accompanies these violins with either trombones or violas, depending upon the Offertory. If the orchestration includes trombones, the fifth instrumental part is a third trombone. If the secondary instrumental parts are violas, the fifth instrumental part is for either a fagotto or bass viola. The instrumentation of the final piece

12 "Ad occurrentes per annum festivitates cum quibusdam de communi." Archiv der Erzdiözese, Dommusikarchiv, Salzburg, A 1148. My translation.

13 BARNDT-WEBB, Miriam. Andreas Hofer: His Life and Music 1629-1684. Ph.D. Dissertation, University of Illinois, Urbana-Champaign, 1972, p. 166.

14 "Offertoriis Potissimum Servituri” Archiv der Erzdiözese, Dommusikarchiv, Salzburg, A 1148. My translation.

15 "Non adornavi ad Magnificentiam, aut peculiare artificicum ut serviant pluribus: velut in vere communis fere florum usus est.” Archiv der Erzdiözese, Dommusikarchiv, Salzburg, A 1148. My translation. 
for the Common of Virgins and Martyrs differs substantially. Two violins and one trombone accompany the eight vocal parts. These diverse soundscapes for worship raise the question of Hofer's intentional use of various instrumentations - a unique quality of the Ver Sacrum collection.

Hofer uses particular instruments or ensembles as musical signs themselves. In his 1961 article, Robert Weaver discussed the representational and programmatic use of instrumentation to create exoteric meaning. ${ }^{16}$ Similarly, in his 1970 dissertation, Symbol Structures in Central European Church Music, Craig Otto studied the liturgical works in the Liechtenstein collection in Kroměřizz and described how musical sign and allegory can communicate extramusical meaning. While the relationship between a musical sign and its referential meaning is arbitrary and therefore must be established through convention, musical allegory involves a more coherent relationship between symbol and meaning. ${ }^{17}$ Composers applied these symbolic procedures not only to individual words, but also to broader sacred concepts, such as the glory and omnipotence of God, sacred events such as the incarnation, crucifixion, or resurrection, and theological concepts such as baptism or the unity of the Christian church.

Both Otto and Weaver identified the use of brass instruments as a musical sign for royalty, secular or sacred. Heinrich Biber represented secular royalty in his Sonata Sancti Polycarpi, an instrumental ensemble sonata that was composed for the installation of Maximilian's nephew Count Polycarp as a provost of the Salzburg Cathedral. The sonata is orchestrated for eight trumpets, kettle drums and continuo. ${ }^{18}$ Instrumental representations of sacred royalty could appear in works of Marian devotion, drawing to the listener's mind the image of Mary as the Queen of Heaven or Jesus as King of Heaven. It is not surprising then, that Hofer uses trombones in the Offertories celebrating the main events of Christ's life in Ver Sacrum: the Nativity, Crucifixion, and Resurrection. Interestingly, brass instruments do not have to be present in the orchestration in order to reference this royal instrumentation. Despite the lack of trumpets in the Offertory for the feast of the Ascension, Hofer imitates the sound of trumpet calls in the violin parts, as the violins play descending fourths and repeated notes imitating the repetitive calls of trumpets. See Example 1. ${ }^{19}$

16 WEAVER, Robert. Sixteenth-Century Instrumentation, Musical Quarterly, 1961, vol. 47, p. 363.

17 OTTO, op. cit., p. 178.

18 BREWER, Charles. The Instrumental Music of Schmeltzer, Biber, Muffat and their Contemporaries. Burlington, Vermont: Ashgate, 2011, p. 242.

19 All of the examples in the paper from my transcription of Andreas Hofer's Ver sacrum seu flores, originally published in Salzburg in 1677. The first violin and bass voice partbooks can be found in the Archive of the Ottobeuren Abbey in Bavaria, Shelf mark 1294. The remaining partbooks are held at the Archiv der Erzdiözese, Dommusikarchiv, Salzburg, A 1148. 


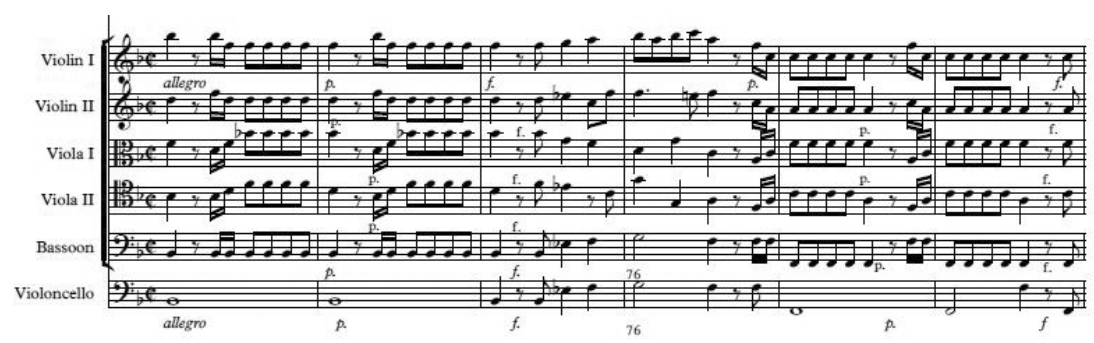

Ex. 1. Hofer, Caelis cives Jubilate, mm. 1-6. Violins imitating trumpets.

Hofer uses a similar technique in the Resurrection Offertory, with open fifths in the first violins in mm. 105-112. See Example 2.



Ex. 2. Hofer, Resurgenti Deo, mm.105-112.

Trombones may also allude to the idea of war and conflict. In the Offertories for the feasts of the Purification of the Virgin and the Common of the Apostles, Hofer uses trombones to articulate martial musical themes. In Estote fortes in bello Hofer uses this texture to represent the adversity that the apostles faced at the early days of the Christian church. In Consurgite fortes, for the feast of 
the Purification, Hofer uses trombones to accompany a text meditating on the Blessed Virgin Mary as the defender of believers, praying for them, and protecting them in times of hardship.

Hofer uses instrumentation to create rhetorical meaning in these concerted settings. In Resurgenti Deo, Hofer's Offertory for Easter, an expanded instrumentation contributes to a dramatic setting of a text expressing the Holy Spirit as a powerful wind. Hofer sets the text spirate venti in a full-voiced instrumentation contrasting greatly with the music that directly precedes it as we can see in $\mathrm{mm}$. 105-112. To further dramatize the echoing of the wind through the valleys, Hofer creates a musical echo effect marking the second iteration of the text spirate venti with a piano. This homophonic, echoing texture is unlike any other section of this piece. It is also in this section that Hofer imitates trumpet calls in open fifths in the violin parts, as mentioned above. Through this broad, expansive instrumentation, Hofer articulates the metaphor of the power of the Holy Spirit as the power of the wind echoing through the valleys of the earth. Please refer back to Example 2.

In his Offertory for the feast of the resurrection, Hofer creates a musical allegory for Christ's rising by opening the work with a rising melody in imitation in the violins. This imitative texture is reiterated and expanded upon shortly thereafter with the text Resurgenti Deo, but the initial musical allegory is articulated by instruments alone in mm. 1-3, as can be seen in Example 3.

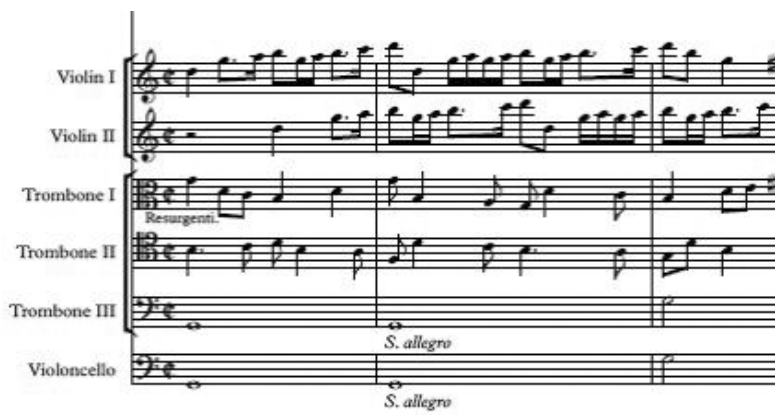

Ex. 3. Hofer, Resurgenti Deo, mm. 1-3.

Hofer illustrates musically the idea of rising up from the grave beginning the imitative entries on the text of the refrain Resurgenti Deo at the bottom of the musical texture and building upwards to eventually include the higher voice parts. See Example 4.

Hofer creates a unique allegory for the glory of God in Vox in Rama, the Offertory of the feast of the Innocents. While the voices introduce the final prayer of the mothers of the innocent slain children and homophonically exclaim "Sub throno DEI", (from under the throne of God) in mm. 120-122, Hofer uses intricate passagework in the violins to represent the elegant glory of the throne of God, the only sixteenth-note flourish in the entire work. See Example 5. 


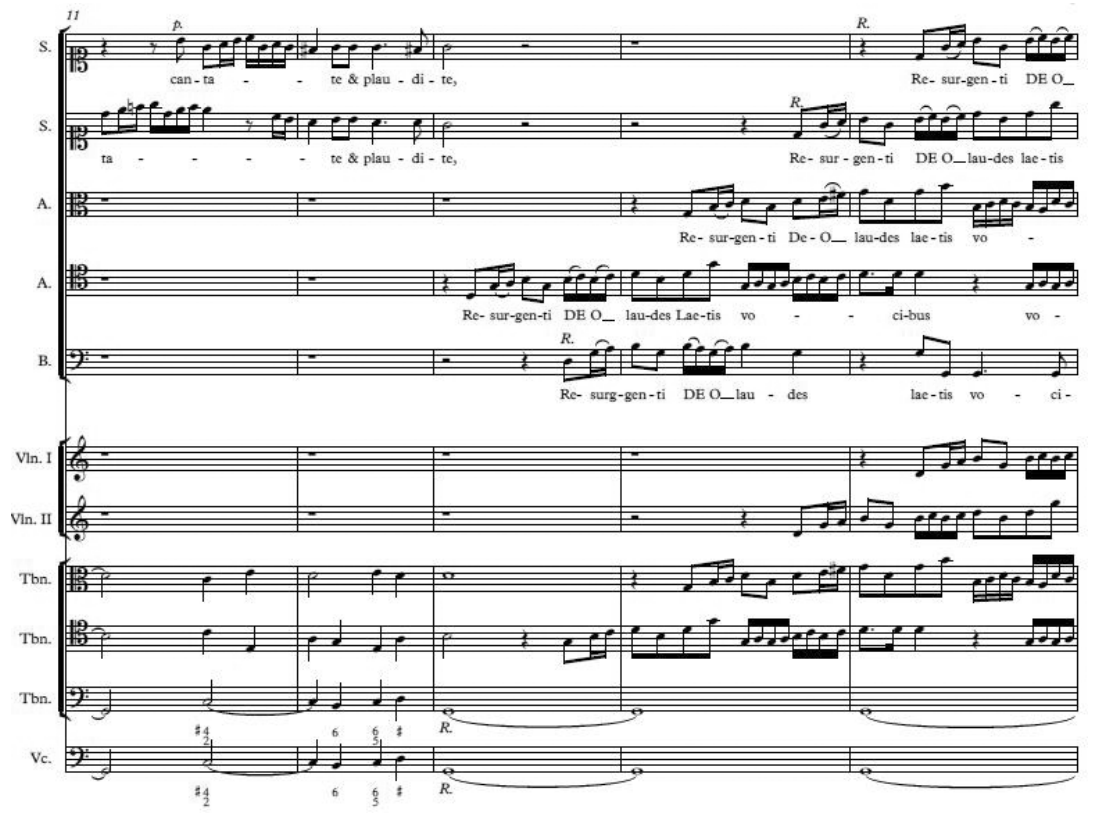

Ex. 4. Hofer, Resurgenti Deo, mm. 11-15.

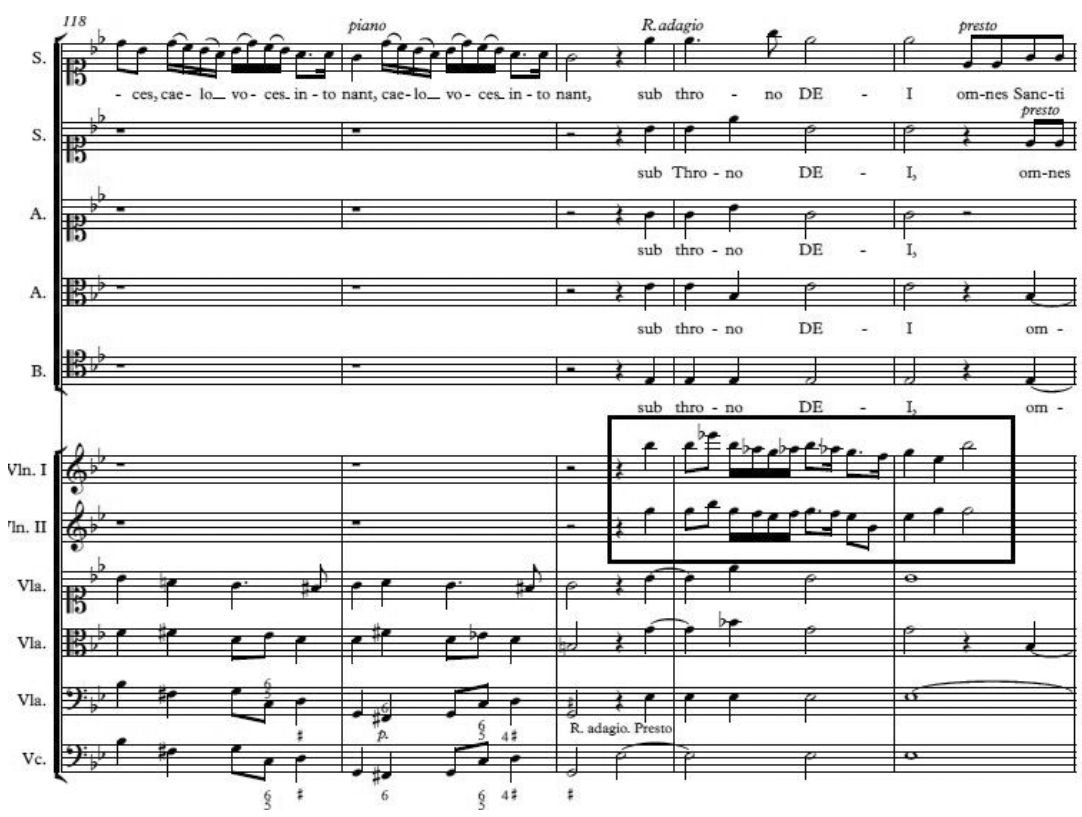

Ex. 5. Hofer, Vox in Rama, mm. 118-122.

Hofer integrates the genre of the instrumental ensemble sonata in the Ver Sacrum. The brief opening sonatas for fourteen of the Offertories are between 6 
and 22 measures in length and employ a variety of musical styles. In the opening sonata for Ad sereni caeli, for the Common of Confessors, the violas provide harmonic support for the two violins that engage in imitation with one another reminiscent of the learned style of the sixteenth century. See Example 6.

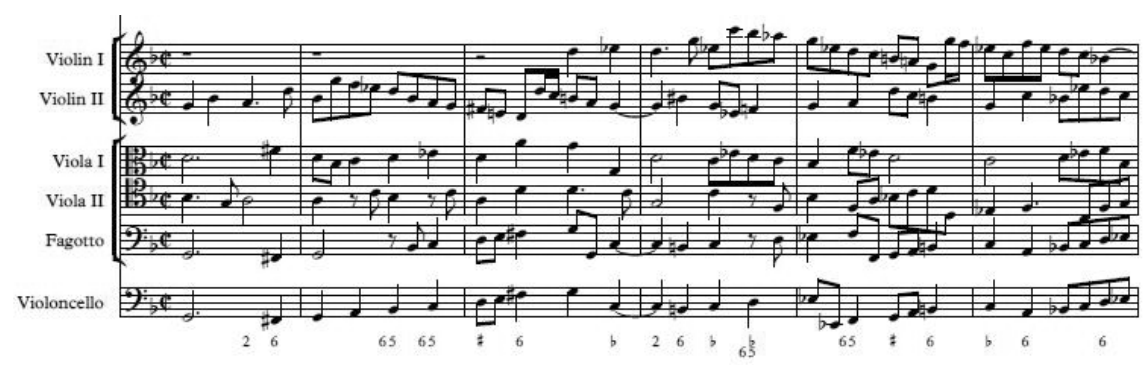

Ex. 6. Hofer, Ad sereni caeli, mm. 1-6.

In contrast, the Offertory for the feast of Corpis Christi, Panis candidissime opens with a sonata that is 22 measures long and in a tri-partite form, complete with a middle section in a slow triple meter. See Example 7.



Ex. 7. Hofer, Panis candidissime, mm. 1-13.

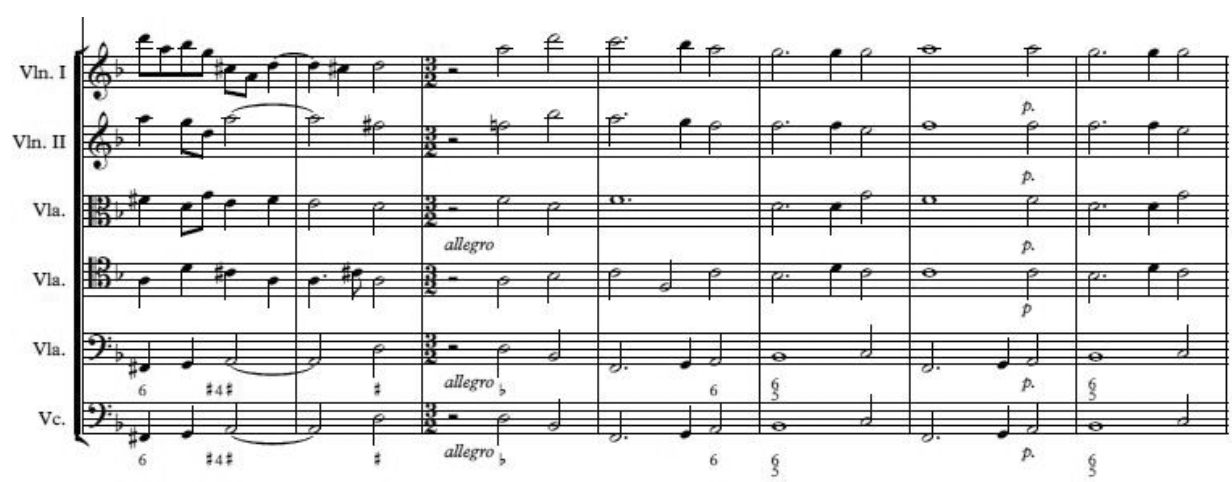

Ex. 7, continued. 
Similarly, Quam Splendita for the Common of a Martyr opens with a two-part sonata with sections in duple and triple meter. In both Panis Candidissime and Quam Splendita, this shift in meter foreshadows the frequent exchange between duple and triple time throughout the remaining music of these Offertories.

Hofer articulates dramatic shifts in the Offertories with brief sonatas, usually 6-8 measures in length. One might not even identify these little intermezzi as sonatas, but Hofer provides the labels "sonata" or "sonatina" in the print. These labels often appear only in the continuo and bass instrument partbooks, so it is possible that Hofer was only providing a cue to the harmonic accompaniment that the singers would not be singing at this time, rather than making a statement with respect to genre. Nevertheless, Hofer includes these labels in the print. In the Offertory for the Feast of the Innocents, Vox in Rama, Hofer inserts a brief five-measure interlude with the label "sonatina" to divide two sections of text: the first describing the innocent infants that are about to be slaughtered and the second describing the soldiers who are seeking, in vain, to murder the infant Jesus. The two violins open the sonatina in an imitative texture while the three violas provide harmonic accompaniment. Although the music seems entirely neutral in character, perhaps Hofer was using this sonatina to dramatically articulate the shift in the text from focusing on the innocent lambs who would be slaughtered and the immortal life of Christ, protected by God. See Example 8.

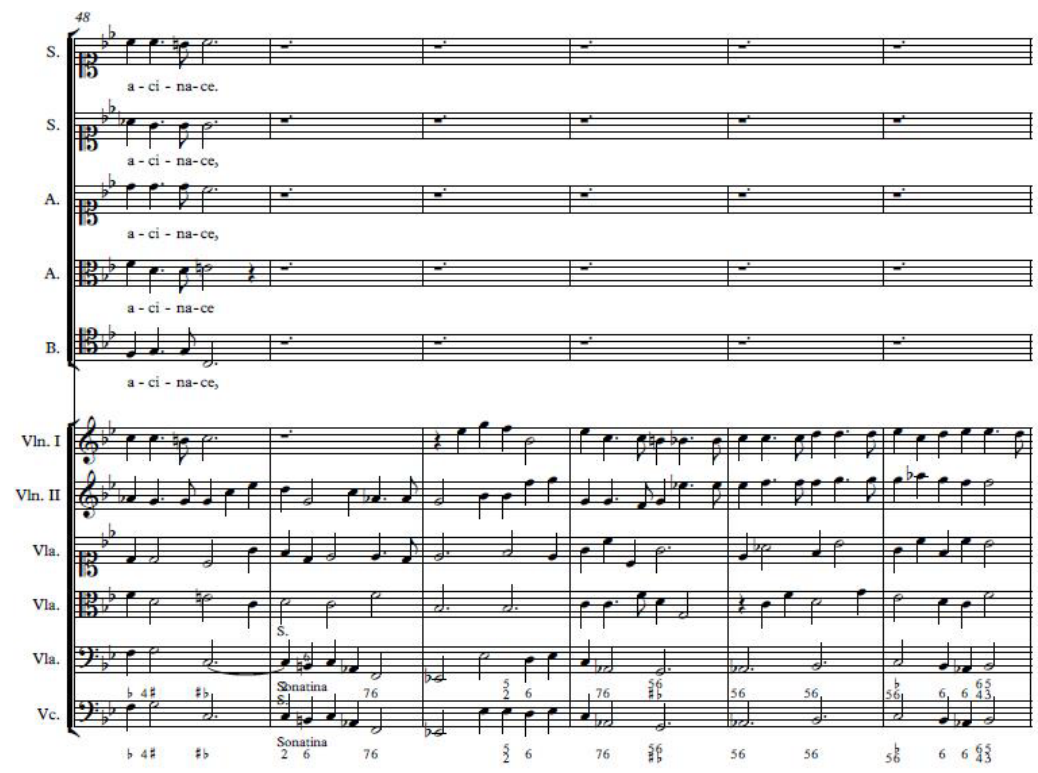

Ex. 8. Hofer, Vox in Rama, mm. 49-54.

Further allusions to the ensemble sonata also appear in the form of brief instrumental episodes that are not always labeled "sonata" or "sonatina." In the Offertory for the Feast of the Resurrection, Resurgenti Deo, Hofer uses instrumental 
interludes to create musical breadth. The offertory is composed of five sections alternating between common time and 3/1 time. In the first triple meter section, Con gaude terra, Hofer uses the instrumental interlude to create musical space

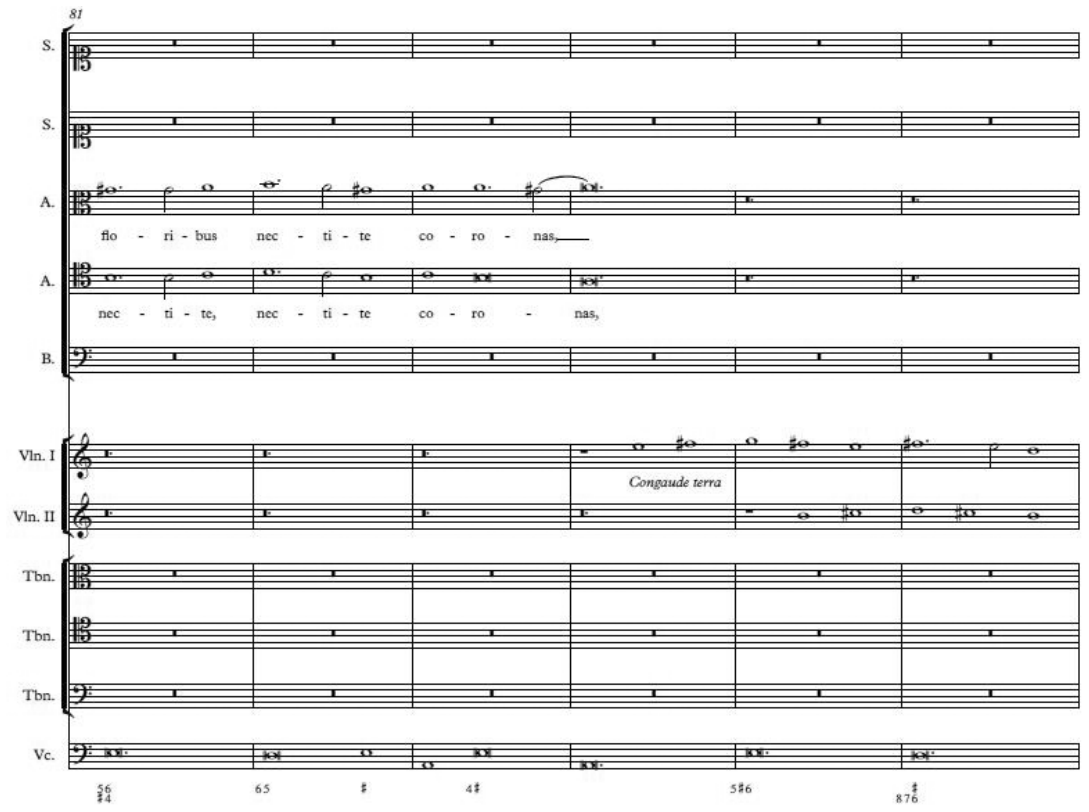

Ex. 9. Hofer, Resurgenti Deo, mm. 81-86.

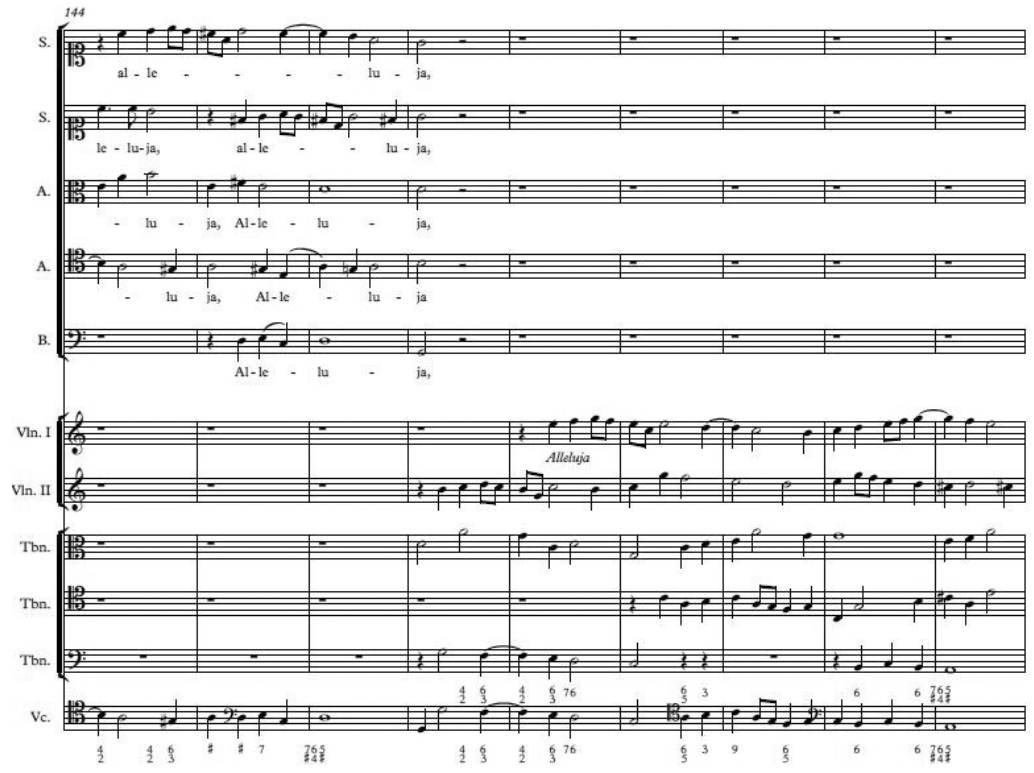

Ex. 10. Hofer, Resurgenti Deo, mm. 144-152. Alleluja Interlude. 
and breadth between multiple iterations of the text "Laetis floribus nectite coronas". See Example 9.

In the second interlude in the final Alleluja in mm.147-152 the instrumental ensemble echoes the imitative motive for the final phrase of the piece that was briefly introduced in the voices in the preceding measures. See Example 10.

Instrumental accompaniment contributes to dramatic expression by increasing the volume and scope of the orchestration to create vast homophonic textures. Towards the end of Vox in Rama, Hofer differentiates between the text of the narrator imploring the cruel soldiers to hear the cries and prayers of the victims and the text of the prayers of the victims. Hofer sets the narrator in a solo cantus voice with a virtuosic melodic line marked "aria": "Hear, wretched and criminal one, what voices are intoning to heaven". A broad, homophonic texture with full instrumental accompaniment then articulates the prayer of the masses being offered up to God, "Avenge, O Lord, our Blood, O our God!" Every possible musical voice is contributing to this prayer. The homophonic texture allows the prayer to ring out loud and clear and the expansive instrumentation reinforces the great strength and power of communal prayers to God. See Example 11.

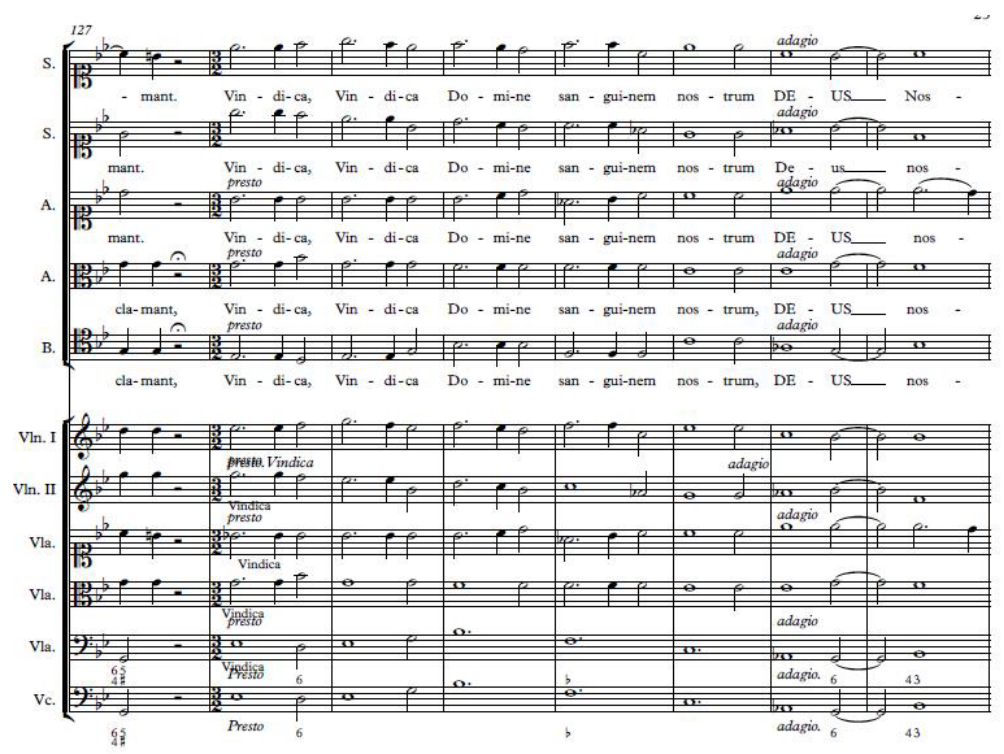

Ex. 11. Hofer, Vox in Rama, mm. 127-134. Homophonic Prayer.

Throughout the liturgical settings of Ver sacrum, Hofer uses instrumental and vocal textures to foster meaning. Concerted instrumentations allow Hofer to set the Offertory texts in the most expressive way possible, adding musical breadth to express the royalty of God and articulating the resurrection and glory of God 
through musical allegory. Brass instrumentations paint a musical picture of the Blessed Virgin Mary as defender of believers, and the apostles as defenders of the faith. Opening sonatas foreshadow the musical textures, and instrumental interludes articulate dramatic shifts. In Ver Sacrum, Hofer clearly demonstrates the expressive ability of instrumental music in liturgical contexts in the seventeenth century.

Kimberly Beck (kimjbeck@gmail.com), University of British Columbia.

\section{ABSTRACT \\ BLENDING THE SECULAR AND SACRED: INSTRUMENTAL TEX- TURES IN SEVENTEENTH-CENTURY WORSHIP}

In the seventeenth century composers employed traditionally secular instrumentations, such as that of the solo violin or ensembles of brass or string instruments, in concerted settings of liturgical texts. While settings of the mass and office are not inherently dramatic, composers used instrumental textures to create dramaturgical effects in these sacred works. As a result, these concerted settings hang in the balance between two sacred genres, the Latin sacred concerto and the oratorio. Moreover, these works demonstrate how composers in the seventeenth century experimented with the blending of genres and evaded the classifications carefully designated by theorists of the period, such as Athanasius Kircher and Michael Praetorious.

Andreas Hofer (c.1629-1684), a composer active in Salzburg for his entire career and the majority of whose surviving works are held in manuscript at Kroměříž, provides an intriguing example of the use of instruments and genre blending in liturgical contexts in his Ver sacrum seu Flores (1677). In this printed collection of eighteen offertories for a variety of instrumental and vocal ensembles, each work is labeled for a particular feast of the church year. Furthermore, Hofer employs instrumentations functioning in a variety of musical capacities, contributing to both the affective and dramaturgical settings of specific passages of text.

In this paper, Hofer's collection demonstrates how composers used instrumental textures to contribute to the expressive and dramatic qualities of sacred works. Following a brief discussion of the role of instruments in sacred contexts in the sixteenth and seventeenth century and methods for communicating meaning with instrumental music in the seventeenth century, I examine Hofer's use of instruments to create particular moods or reference specific topics, such as those of war and devotion, in liturgical contexts. Finally, I describe how Hofer used these techniques in the Offertories of Ver sacrum seu flores. Ultimately, this paper shows how Hofer deploys the expressive ability of instrumental music in liturgical contexts in the seventeenth century, blending characteristics of both the Latin sacred concerto of the seventeenth century and the burgeoning genre of oratorio in the eighteenth century.

\section{Key words}

Instrumental Music, Salzburg, Offertories, Andreas Hofer

\section{Bibliography}

BARNDT-WEBB, Miriam Wagoner. Andreas Hofer: His Life and Music 1629-1684. Ph.D. Dissertation, University of Illinois, Urbana-Champaign, 1972.

BLAZEY, David. A Liturgical Role for Monteverdi's Sonata sopra Santa Maria. Early Music, 1989, vol. 17, pp. 174-182. 
BONTA, Stephan. The Uses of the 'Sonata da chiesa.' Journal of the American Musicological Society, 1969, vol. 22, pp. 54-84.

BONTA, Stephan. The Use of Instruments in Sacred Music in Italy 1570-1700. Early Music, 1990, vol. 18 , pp. 519-536.

BRAUER, James Leonard. Instruments in sacred vocal music at Braunschweig-Wolfenbüttel: a study of changing tastes in the seventeenth century. Ph.D. Dissertation, City University of New York, 1983.

BREWER, Charles. The Instrumental Music of Schmeltzer, Biber, Muffat and their Contemporaries. Burlington, Vermont: Ashgate, 2011.

CARTER, Tim. Resemblance and Representation: Towards a New Aesthetic in the Music of Monteverdi. In Con Che Soavità: Studies in Italian Opera, Song, and Dance, 1580-1740. Edited by Iain Fenlon, et al. Oxford: Clarendon Press, 1995, pp. 118-134.

CHAFE, Eric Thomas. The Church Music of Heinrich Biber. Ann Arbor, Michigan: UMI Research Press, 1987.

FRANDSEN, Mary. The Sacred Concerto in Dresden, ca. 1660-1680. Ph.D. Dissertation, Eastman School of Music, 1996.

KENDRICK, Robert. "Devotion, piety, and commemoration: sacred songs and oratorios." In The Cambridge History of $17^{\text {th }}$-Century Music. Edited by Tim Carter and John Butt. Cambridge: Cambridge University Press, 2005, pp. 324-377.

KORRICK, Leslie. Instrumental Music in the Early $16^{\text {th }}$-Century Mass: New Evidence. Early Music, 1990, vol. 18, pp. 359-370.

MALOY, Rebecca. Inside the Offertory. Oxford, Oxford University Press, 2010.

MALOY, Rebecca. The Word-Music Relationship in the Gregorian and Old Roman Offertories. Studia Musicologica Academiae Scientiarum Hungaricae, 2004, vol. 45, pp. 131-148.

OTTO, Craig Allen. "Symbol structures in Central European church music: aspects of the wordtone relationship in the mid- to late seventeenth century." Ph.D. Dissertation, Syracuse University, 1978.

ROCHE, Jerome. On the Border Between Motet and Spiritual Madrigal: Early $17^{\text {th }}$ Century Books that Mix Motets and Vernacular Settings. In Seicento inesplorato: levento musicale tra prassi e stile. Edited by Alberto Colzani. Como, Italy: A.M.I.S, 1993, pp. 303-31.

ROSENTHAL, Karl August. Zur Stilistik der Salzburger Kirchenmusik von 1600-1730. Studien zur Musikwissenschaft, 1930, vol. 18, pp. 77-94, 1932, vol. 19, pp. 3-32.

SELDFRIDGE-FIELD, Eleanor. Venetian Instrumental Music from Gabrieli to Vivaldi. New York and Washington: Praeger Publishers, 1974.

WEAVER, Robert L. Sixteenth-Century Instrumentation. Musical Quarterly, 1961, vol. 47, pp. 363-378. 